\title{
Ultrastructure and Histochemistry of the Submandibular Gland of the European Hedgehog, Erinaceous europaeus L.
}

\author{
I. Acinar Secretory Cells \\ Bernard Tandler and Donald K. MacCallum \\ Department of Oral Biology, School of Dentistry, Case Western Reserve \\ University, Cleveland, Ohio 44106, and Departments of Oral Biology and Anatomy, \\ University of Michigan, Ann Arbor, Michigan 48104
}

Received September 20, 1971

\begin{abstract}
The ultrastructure and histochemistry of the submandibular gland of the European hedgehog was examined. The gland was of the mixed type, consisting of approximately equal numbers of mucous and serous cells. On the basis of staining reactions, it was concluded that the mucous droplets contained only one type of mucin, a periodate-reactive sialomucin, and that the serous granules contained glycoprotein. At the ultrastructural level, it was found that the mucous droplets often contained a dense spherule, and that their matrix was responsive to variations in fixation procedures. The serous granules developed in a remarkable fashion. Small, dense rodlets in Golgi-derived vacuoles became aligned to form a series of concentric dense shells. The intervals between shells became filled with small, dense particles. These particles, coupled with condensation of the granules, led to increasing densification of the granule matrix. The contents of mature serous granules were liberated by a merocrine process into the acinar lumen, where they disintegrated.
\end{abstract}

European hedgehogs are members of the Order Insectivora, the most "primitive" of the true placental mammals. Because of their "lowly" phylogenetic estate, and because they hibernate, these animals attracted the attention of many turn-of-thecentury microscopists. The readily accessible submandibular gland was a popular organ for study, and detailed descriptions were published by Kultschizky (45), Krause (44), and Loewenthal (52). More recently, Schmidt (69) compared the salivary glands from hibernating and nonhibernating hedgehogs, and Borghi $(9)$ reported several of their histochemical reactions.

The enzymatic content of erinaceous submandibular saliva was assayed by Hirsch and Junqueira (31), who found that amylase activity was virtually absent, and that DNase and lysozyme were negligible. There was some protease activity, but this was rather low when compared to rat or mouse submandibular glands. According to 
TABLE I

Selected Carbohydrate Histochemistry of Hedgehog Submandibular Gland

\begin{tabular}{|c|c|c|}
\hline Treatment & Mucous Cells ${ }^{a}$ & Serous Cells ${ }^{a}$ \\
\hline 1. Schiff's reagent & - & _ \\
\hline 2. Periodic acid $\left(\mathrm{HIO}_{4}\right)-$ Schiff & +++ & + \\
\hline 3. Alcian blue-HIO ${ }_{4}$-Schiff* & $+++(\mathrm{Ab})$ & $+++(\mathrm{S})$ \\
\hline 4. Low iron diamine-Alcian blue & +++ (lid) & - \\
\hline 5. $\mathrm{HIO}_{4}$-low iron diamine & +++ & - \\
\hline 6. High iron diamine & - & - \\
\hline 7. $\mathrm{HIO}_{4}$-high iron diamine & +++ (purple) & -- \\
\hline 8. $\mathrm{HIO}_{4}-p$-diamine (96 hours) & +++ (purple) & - \\
\hline 9. Alcian blue (pH 2.5)-aldehyde fuchsin & $+++(\mathrm{Ab})$ & - \\
\hline
\end{tabular}

$a+++=$ strongly positive; $+=$ moderately positive, distinct, but moderate coloration; $-=$ negative; $*=$ infrequently, intensely magenta colored mucous cells were observed.

Junqueira et al. (38), hedgehog submandibular saliva also contained a relatively substantial concentration of sialic acid.

Because other organs in the hedgehog have been found to possess many unusual features at the ultrastructural level $(32,51,80)$, it was felt that detailed examination of the submandibular gland by electron microscopy and by modern histochemical means would be of interest. The results are reported in this article. It was found that the serous granules were highly specialized, with a substructure unique among mammalian salivary glands.

\section{MATERIALS AND METHODS}

Seven active, nonhibernating, adult European hedgehogs (Erinaceous europaeus L.) five females and two males - were used in this study. They were fed an ad libitum diet of ground horsemeat, fresh lettuce, and Purina Stars, and had free access to water. To obtain tissues for microscopical examination, the animals were lightly anesthetized with Nembutal, and the chest cavity was exposed. One submandibular gland was carefully extirpated and cut in half. One portion was fixed by immersion in phosphate-buffered $2 \%$ osmium tetroxide (56), while the remainder was processed for light microscopic histochemistry. The contralateral submandibular gland was fixed by vascular perfusion via the left ventricle. The perfusate was either half- or full-strength Karnovsky's fixative (40) buffered with phosphate. A single animal was perfused with a mixture of acrolein, formaldehyde, and glutaraldehyde buffered with chromate-dichromate. The specimens were rinsed in saline, then postfixed in $2 \%$ osmium in the same buffer as the perfusate. Dehydration in ethanol and propylene oxide was followed by embedment in Maraglas-D.E.R. 732 (18). Thin sections were stained with methanolic uranyl acetate (78) and lead tartrate (57), and examined and photographed in a Siemens Elmiskop 1a electron microscope. For light microscopic examination, epoxy sections $1 \mu$ thick were stained with toluidine blue, and photographed in a Zeiss Ultraphot equipped with planapochromatic objectives. 
For histochemistry, tissues were fixed in $10 \%$ formalin neutralized with calcium acetate, or in alcohol-formalin-acetic acid. After dehydration in graded ethanol and passage through two changes of dioxane, the tissues were embedded in paraffin. Sections 5-7 $\mu$ thick were subjected to the procedures listed in Table I, using methods reviewed by Spicer et al. (76).

\section{Light microscopy}

\section{OBSERVATIONS}

The submandibular glands were compound tubuloacinar glands of the mixed type, containing both mucous and serous elements in approximately equal numbers (Fig. 1). The acini were variable in cellular composition; some consisted entirely of mucous cells, but most were mixed (Fig. 2). In paraffin sections stained with hematoxylin and eosin, the eosinophilic serous cells, which usually formed a cluster within each acinus, were capped by a demilune of pale-staining mucous cells. With mucicarmine or PAS staining, the tinctorial pattern was reversed, with deeply stained mucous cells capping clusters of paler serous cells. In $1 \mu$-epoxy sections, the serous granules were rendered with great clarity, appearing almost black after being stained with toluidine blue (Fig. 2).

\section{Histochemistry}

The histochemical reactions of the hedgehog acinar secretory cells are summarized in Table I. Since all mucous cells reacted identically, it appears that the hedgehog submandibular gland contains only ne tyne nf histochemicallv classifiahle mucin a

periodate-reactive sialomucin $(48,49)$. The serous granules were stained by the PAS technique, suggesting that they, like most zymogen granules, have a glycoprotein composition (50).

\section{Electron microscopy}

The basal plasmalemma of the acinar cells was smooth in contour, without infoldings, and rested on a basal lamina. The lateral cell membranes were relatively straight, with only occasional interdigitating processes. Adjacent acinar cells, regardless of type, were joined by numerous desmosomes, and a junctional complex was present at the apical perimeter of these cells. Mitochondrial-desmosomal complexes were often observed along the plasma membranes of confronted acinar cells. Myoepithelial cells were common, and were present in their usual position between basal lamina and overlying secretory cells (83).

Mucous cells. The mucous cells were characterized by numerous mucous droplets and a basally displaced nucleus. The nuclei were scalloped in outline, were extremely electron-dense, and often contained a large nucleolus. The ultrastructural appearance of the mucous droplets depended in large measure on the fixative used. Figures 3-6 

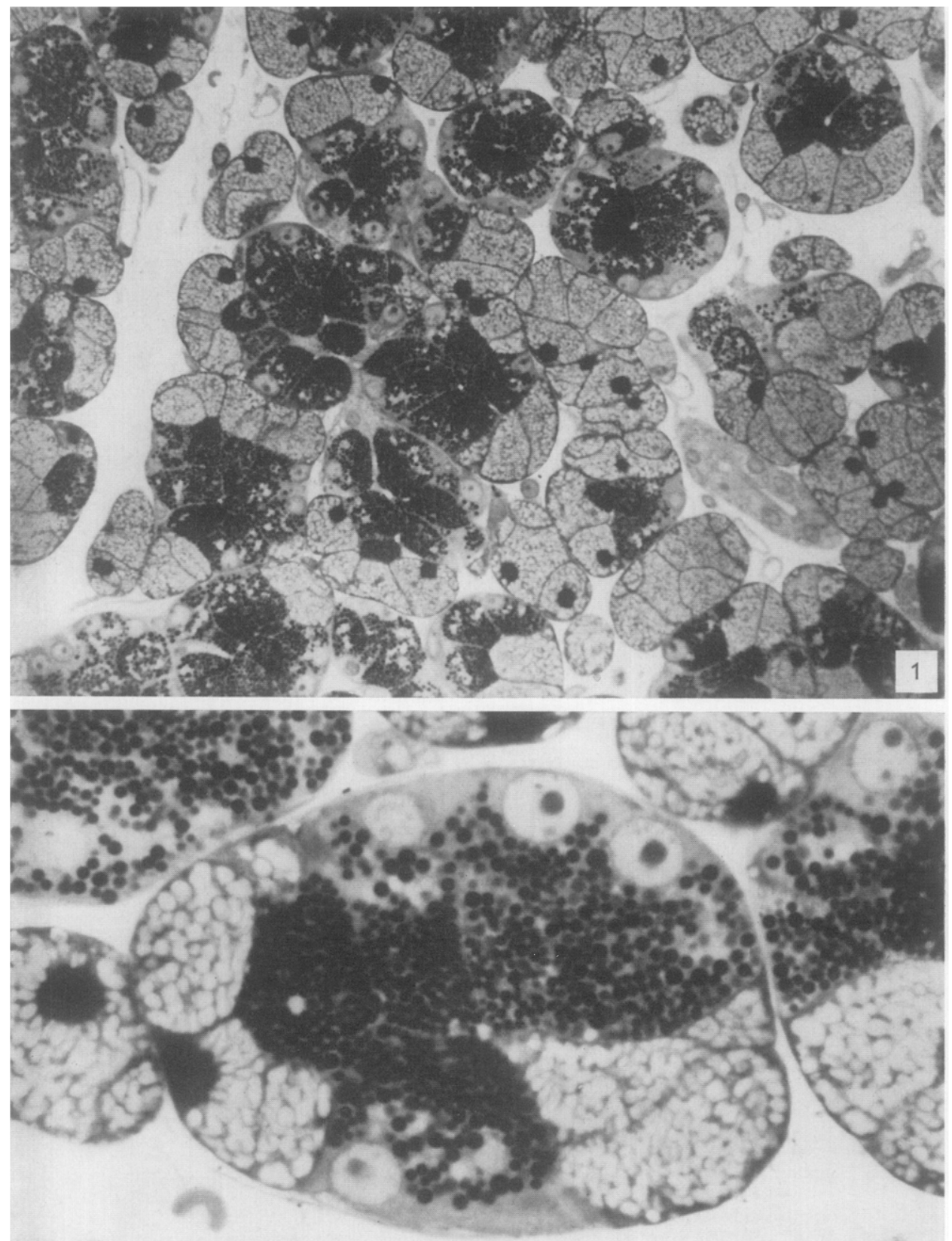

Fig. 1. Survey photomicrograph of hedgehog submandibular gland embedded in epoxy resin. Secretory granules in the serous cells are densely stained, while mucous droplets are lightly stained. Toluidine blue. $\times 490$.

FIg. 2. Photomicrograph of a mixed acinus. Note the high density of nuclei in mucous cells compared to those in serous cells. Toluidine blue. $\times 1625$. 
demonstrate the variation in density of the mucous droplets under four different fixation procedures. With fixation by immersion in osmium tetroxide, the matrix of the droplets was extremely pale, containing numerous, widely separated specks of material of low electron density. Many droplets contained a single dense spherule, often somewhat flattened, and usually eccentrically placed (Fig. 3). Perfusion fixation with half-strength Karnovsky's fixative followed by osmium resulted in a mixed population of droplets, some with an extremely pallid matrix, and others with a matrix of appreciable density (Fig. 4). While dense spherules were present in both light and dark droplets, they tended to be more frequent in the latter. Perfusion with full-strength Karnovsky's fixative followed by osmium yielded a uniform population of droplets with a finely granular matrix of high electron density (Fig. 5). The dense spherules appeared to have a light center. Perfusion with a mixture of aldehydes buffered with chromate-dichromate followed by chrome-osmium produced droplets with a granulofibrillar matrix of variable density (Fig. 6). Unlike the droplets fixed by the other procedures, dense spherules were completely absent.

Regardless of fixation, the cytoplasmic matrix observed in the interstices between the mucous droplets was extremely dense. The occasional cisterns of granular endoplasmic reticulum invariably contained material of considerable density. Free ribosomes were abundant, and a few Golgi saccules were observed.

Serous cells. The serous cells contained large nuclei, which were neither as electron dense nor as basally situated as those in the mucous cells, and which often exhibited one or two prominent nucleoli. An extensive granular endoplasmic reticulum (Fig. 8), which contained finely fibrillar material (Fig. 9), occupied the cytoplasm below and lateral to the nucleus and sent cisterns into the supranuclear cytoplasm. The latter region of the serous cells was characterized by a large assortment of cytoplasmic granules of varying complexity (Fig. 7). These granules represented stages in the maturation of the secretory product of the serous cells, and could easily be arranged in a developmental sequence.

The earliest suggestion of granule formation was observed within the Golgi complexes (Fig. 10). These organelles were abundant in the apical cytoplasm. They usually consisted of three or four flattened saccules, forming a dictyosome, and numerous small vesicles. At their ends, the saccules were expanded to form pyriform or flaskshaped bulbs. A few dense rodlets and some rather amorphous globules often were present in these terminal expansions. The expansions appeared to pinch off from the

FIG. 3. Mucous droplets fixed solely by osmium. $\times 37000$.

Fig. 4. Mucous droplets fixed with half-strength Karnovsky's fixative followed by osmium. $\times 25000$ FIG. 5. Mucous droplets fixed with full-strength Karnovsky's fixative followed by osmium. $\times 37000$. Fig. 6. Mucous droplets fixed in a mixture of chromate-buffered aldehydes followed by chromeosmium. $\times 16000$. 

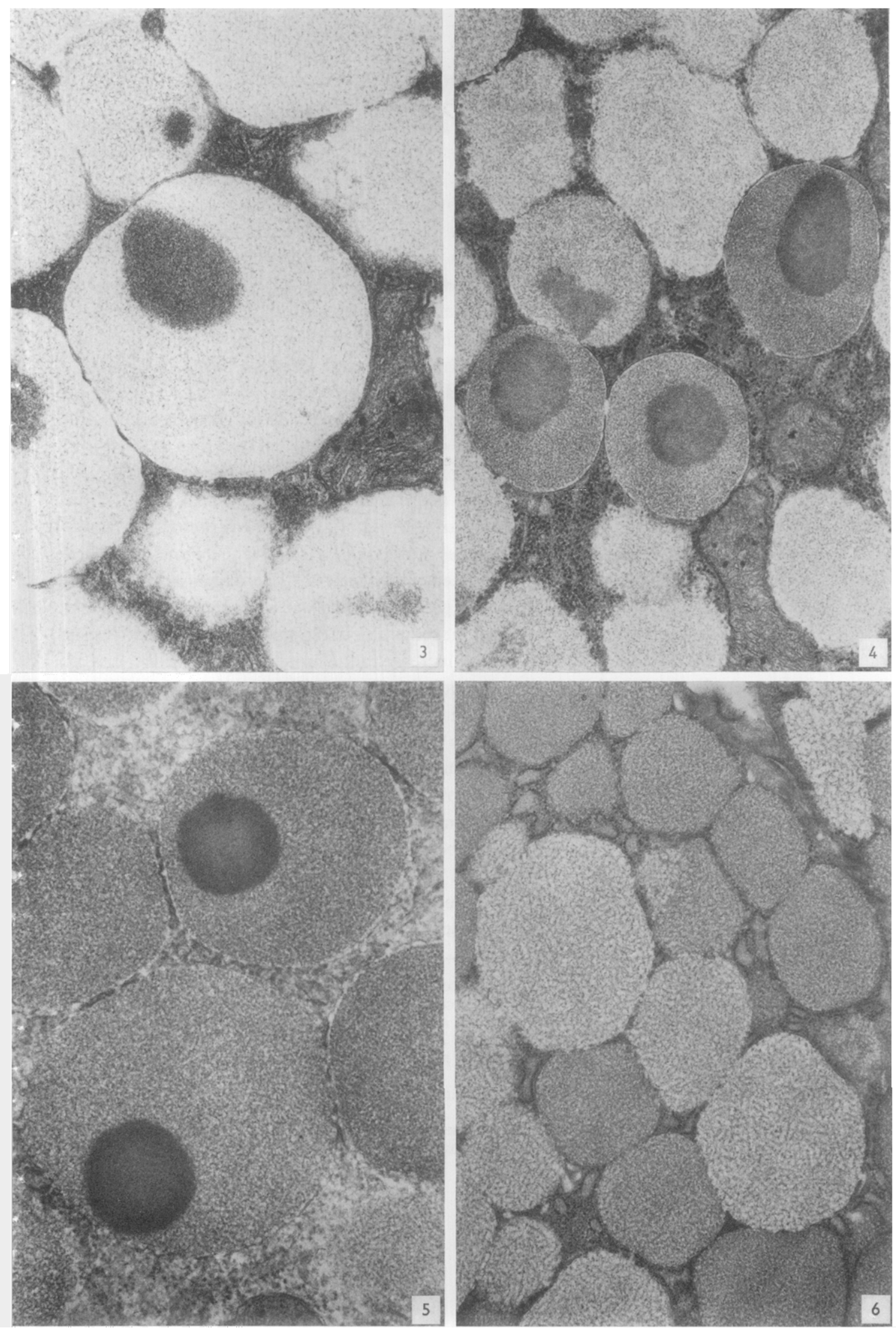
Golgi saccules, forming a progression of vacuoles of increasing size, the largest vacuoles attaining a diameter of slightly more than $2 \mu$. The larger vacuoles frequently were positioned within the concavity of the dictyosome. Numerous transitional elements of the endoplasmic reticulum, many of which showed bud formation, were present in the vicinity of the Golgi complexes and the emergent vacuoles. Small vesicles, equal in size to the buds on the transitional elements, were often observed fusing with the smaller to moderate sized vacuoles (Fig. 11). The latter structures, together with some of the larger vacuoles, contained a jumbled profusion of dense rodlets and globules from which fine fibrils extended into the vacuole matrix (Fig. 12). As the vacuoles continued to mature, the rodlets and globules began to aggregate end-to-end to form longer rods and small laminar structures. At a later stage, these were assembled as a series of concentric, uniformly thick, dense shells suspended in a matrix of low density, so that in thin section these nascent secretory granules resembled targets (Fig. 13). As many as a dozen shells could be found in a single granule. At this stage of development, individual dense shells were about $300 \AA$ thick. While adjacent dense shells were separated by an interval of about $750 \AA$, occasional interconnections were present. As the granules continued to mature, there was a marked reduction in their diameter, until they measured about $1.2 \mu$, a decrease of approximately $40 \%$. With decreasing size of the granules, there was an increase in the thickness of the dense shells, and a concomitant reduction in the space between neighboring shells (Fig. 14). In addition, there was an increase in the number of cross-links, and an increase in the density of the matrix. In part the latter condition was due to condensation of the matrix, but was primarily due to the appearance of dense, $100 \AA$ particles between the dense shells (Fig. 15). At this point, the granules were sufficiently mature to be liberated from the cell. Some granules, however, underwent further condensation prior to extrusion. They consisted of a dense matrix representing ferruminated dense shells, and barely discernible streamers of $100 \AA$ particles (Fig. 16).

The mature secretory products were liberated from the serous cells by a merocrine process. In order to observe the actual extrusion of the granule contents, it was necessary to study tissue fixed by immersion, rather than by perfusion. It would appear that the saline lavage of the vascular system preceding introduction of the

FIG. 7. Survey electron micrograph of a serous cell, showing many serous granules in various stages of maturation. A mitochondrion-desmosome complex is at the upper left corner. $\times 22000$.

FIG. 8. A horizontal section through a serous cell showing an area of cytoplasm lateral to the nucleus. Granular endoplasmic reticulum is abundant. $\times 20500$.

FTG. 9. Cisterns of rough-surfaced endoplasmic reticulum containing granulofibrillar material. TE, transitional element. $\times 60000$.

Fig. 10. A Golgi complex with terminally expanded saccules containing dense secretory material. $\times 67000$.

FIG. 11. A condensing vacuole containing numerous dense rodlets and irregular plates. $\times 61000$.

Fig. 12. A vesicle (arrow) in the process of fusing with a condensing vacuole. $\times 68000$. 


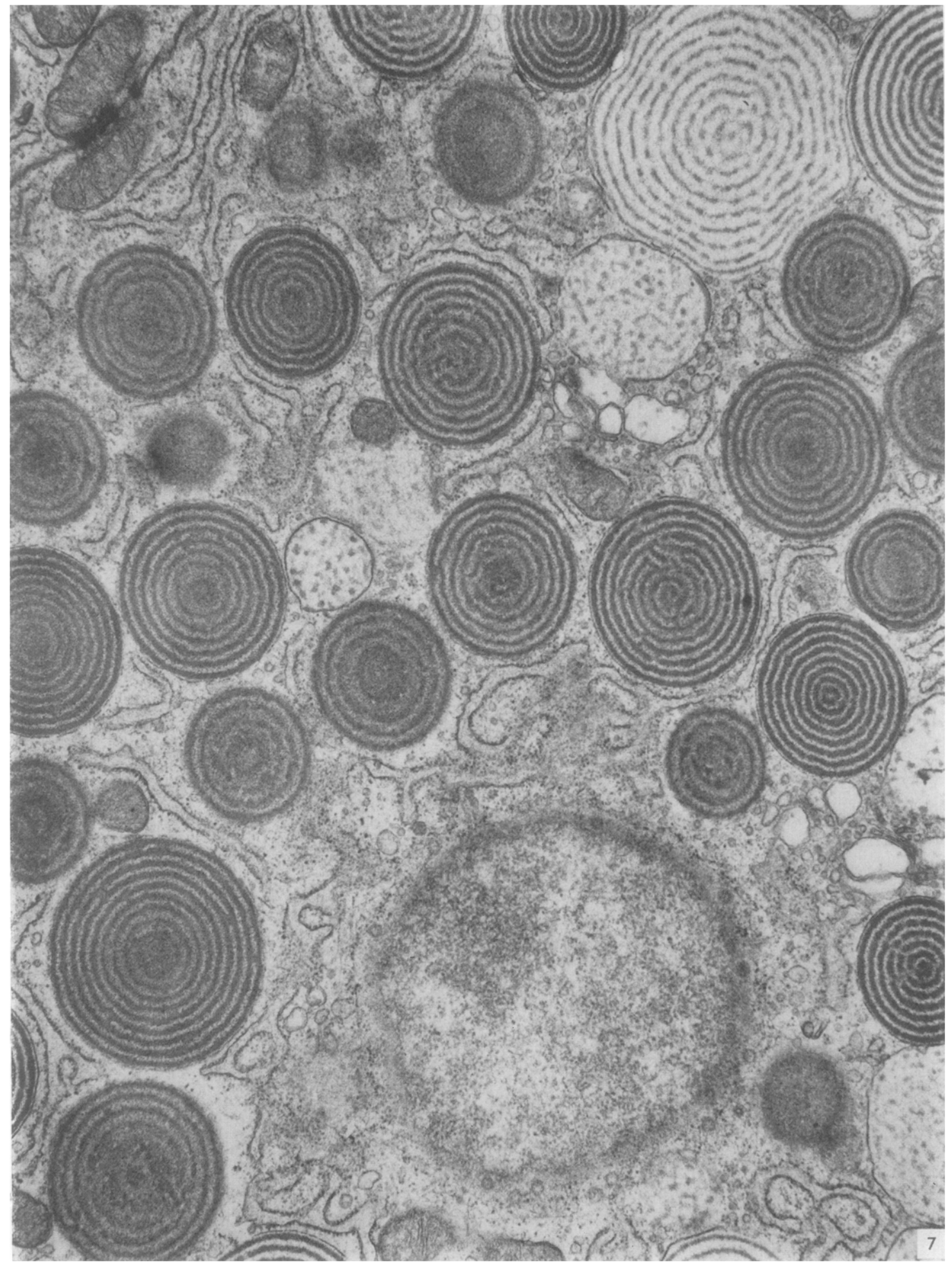




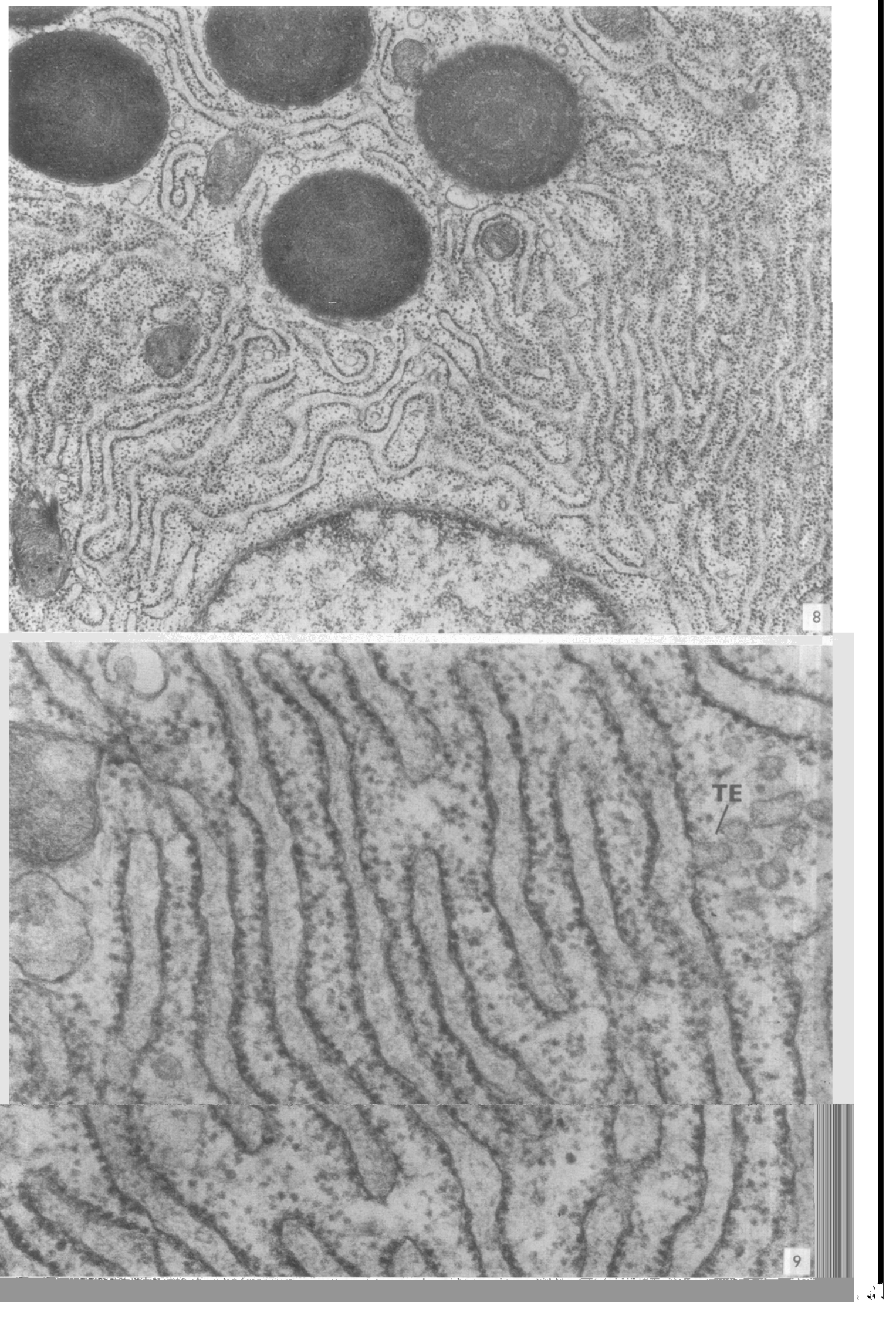




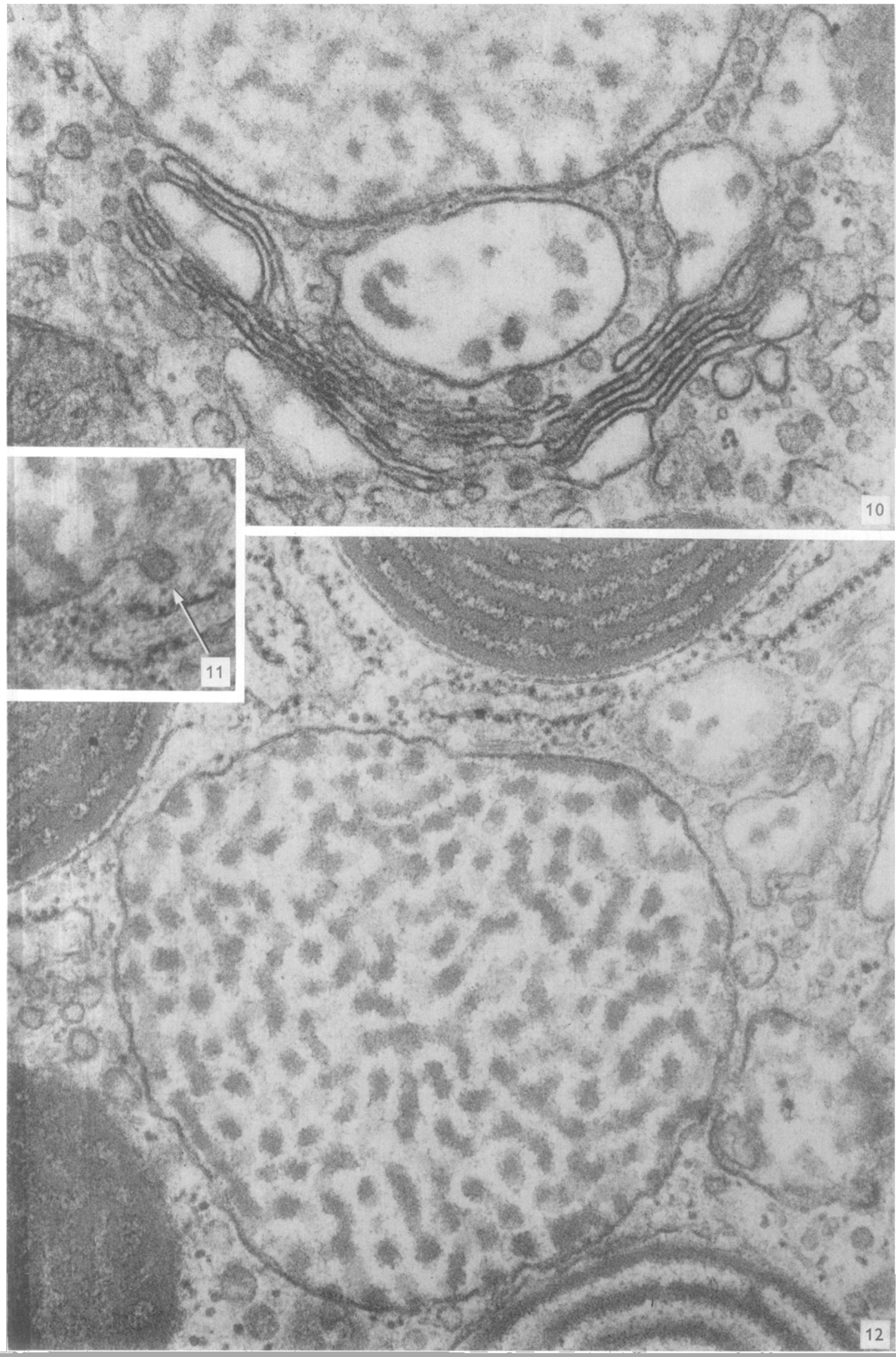


fixing fluid in some way produced a total cessation of the liberation of the secretory granules. When specimens of erinaceous submandibular glands were fixed by immersion, all stages in the merocrine process were easily observed.

The sequence here illustrated was taken from tissue fixed by immersion in osmium tetroxide. The appearance of the secretory granules after this fixative was, with one exception, very similar to that resulting from aldehydes and osmium applied in tandem. The only structures not preserved by osmium used alone were the $100 \AA$ particles in the matrix of the targetlike secretion granules (Fig. 17). As a result, the matrix in such granules was extremely electron lucent. More cross-links between adjacent dense shells were noted than in the aldehyde-osmium-fixed granules.

The first step in the extrusion of the serous granules was the fusion of the limiting membrane of the granule with the apical plasmalemma, so that only a single unit membrane stood between the contents of the granule and the acinar lumen (Fig. 18). This barrier then ruptured and the granule contents were expelled in toto into the lumen (Figs. 19 and 20). The resultant omega-shaped invaginations of the plasma membranes imparted a highly scalloped and irregular appearance to the lumen (Fig. 21). The granular contents, which initially retained their original geometry, soon began to depolymerize within the lumen (Fig. 20). The degradation of the dense shells continued until all that remained were small, dense fragments resembling those observed in the expanded saccules of the Golgi complex (Fig. 21).

\section{DISCUSSION}

The contents of secretory granules in various exocrine cells can assume a multiplicity of forms, ranging from uniformly dense material with no apparent substructure $(14,21,26,43)$, to highly ordered, complex arrangements. Among the configurations adopted by granule contents are focal deposits of dense material in a less dense matrix $(7,41,58-61)$, randomly oriented filaments $(55)$, bundles of parallel filaments $(10,22,23,33,35,79)$, admixtures of random and ordered filaments $(5,8)$, twisted and interconnected ribbons $(6,81)$, microtubules $(12,19,29,33,34,54,73,75)$, crystals $(3,4,8,30,47,67,71,81,86,87)$, and lamellae (63). This is by no means an exhaustive list; variations are apparently endless.

The serous granules of hedgehog submandibular gland are among the most highly organized secretory granules ever described, especially among the mammals. No inkling of their complexity is afforded by their histochemistry or by the paucity of digestive enzymes in hedgehog submandibular saliva (37). In some exocrine cells, secretory granules can be arranged in a developmental sequence on the basis of progressively increasing density. Such is the case in both the fetal and adult exocrine pancreas $(36,74)$, and in the adult parotid gland $(27)$. Because of their steadily in- 

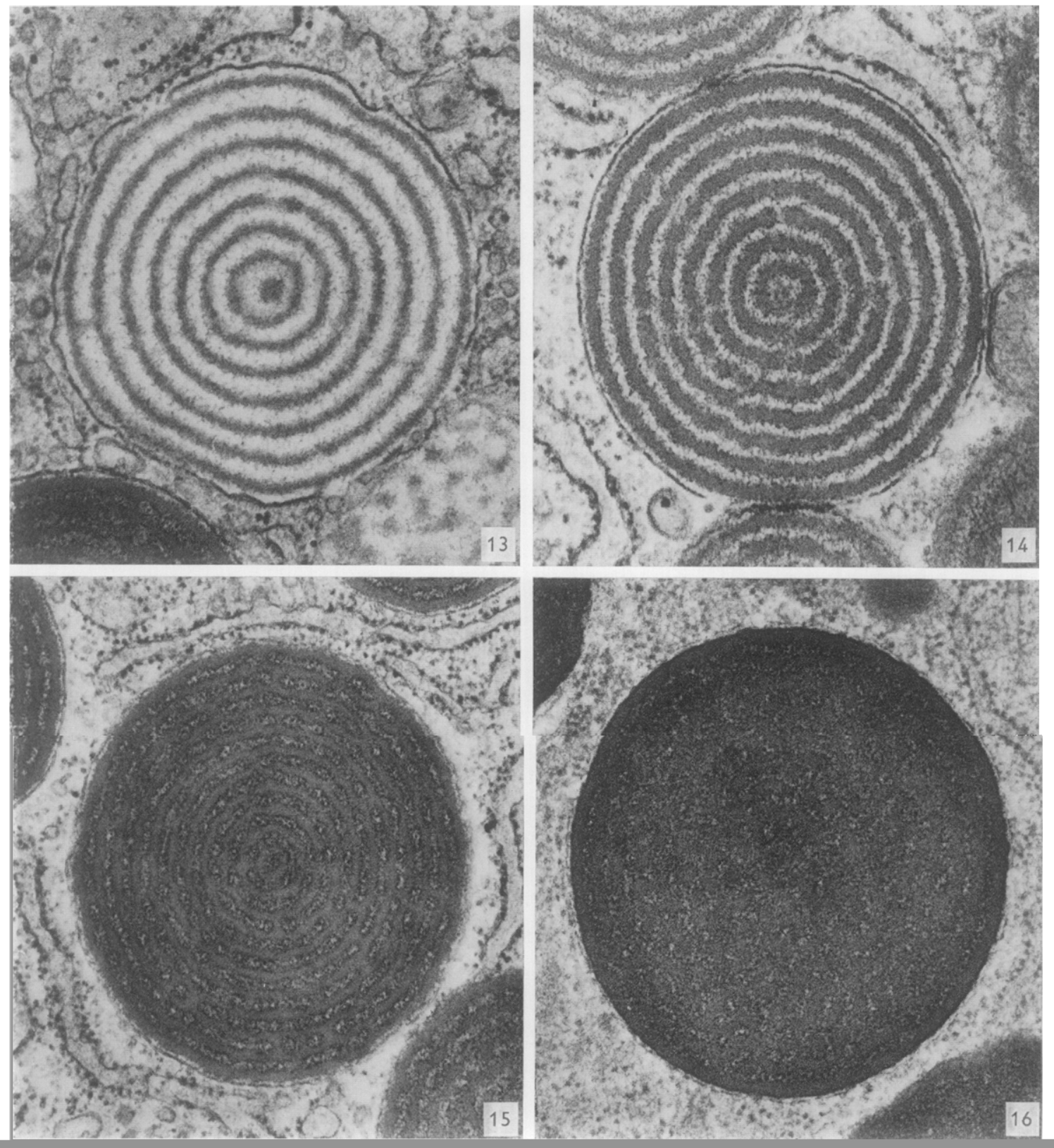
creasing complexity, the granules in the hedgehog provide an unparalleled opportunity for reconstruction by purely morphologic means of the maturation of a complicated secretory product. In early stages, these granules appear to follow the same ontogenic pathway as in the exocrine pancreas. Thus, secretory product initially appears within the cisterns of granular endoplasmic reticulum. Numerous vesicles arising from transitional elements of the endoplasmic reticulum ferry newly synthesized material to the Golgi complex. On the basis of nucleoside diphosphatase activity (24), incorporation of labeled sugars (25), and the presence of glycosyltransferases (68), it has been demonstrated in other cells that the Golgi complex is the site where carbohydrate is added to protein. Erinaceous serous granules probably contain glycoprotein, and it appears that the Golgi complex plays a pivotal role in their elaboration.

Instead of directly producing condensing vacuoles, the Golgi complex per se appears to have the capacity to concentrate secretory material, at least in early stages of granule development. Dense material may be observed within expanded peripheral Golgi saccules while they still are a constituent part of the Golgi complex. These dilatations eventually separate from the Golgi membranes, and, at this juncture, begin to function as condensing vacuoles. Small vesicles, presumably carrying additional protein, fuse with the vacuoles, which progressively increase in size. The dense material becomes organized in concentric shells, and the granules begin to shrink, probably by expulsion of a liquid phase. Secondarily, dense particles fill the spaces between the shells. Continuation of these processes may culminate in obliteration of substructure in the granule matrix. 


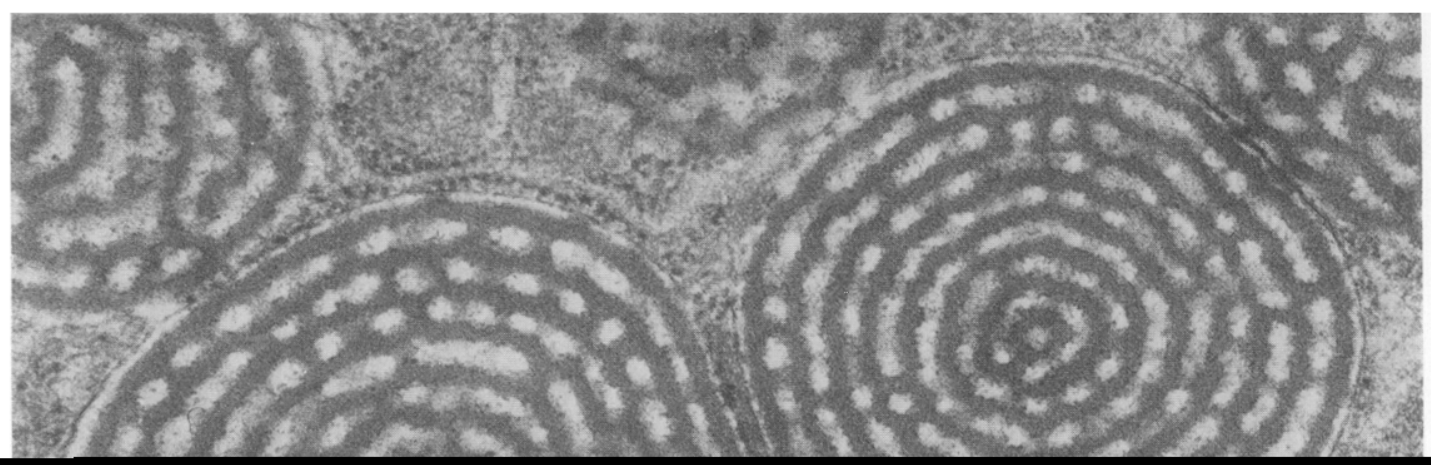


$66,85)$, small granules $(17,88)$, ribbons of dense material arranged in whorls or striae $(28,39,46,64,72,84)$, tubules $(42,88)$, or paracrystalline arrays (53). No known adult salivary gland, however, has granules matching those of the hedgehog in structural complexity.

It should be noted that several invertebrates possess cells that produce granules morphologically equivalent to erinaceous serous granules. These cells have been illustrated and cursorily described in the basal disk of hydra (63), the pericardial sac of the land crab (15), the mantle epithelium of the snail (65), and the statocyst epithelium of the crayfish (77). The appearance of granules in the latter cells prompted Steinbrecht (77) to give them the rather fanciful name of "op-art-bodies." Because of their sporadic occurrence, none of these granules lend themselves to developmental or biochemical study. The cortical granules of mature unfertilized eggs of certain sea urchins, however, not only resemble hedgehog serous granules, but can be analyzed by a variety of methods, including isolation and biochemical characterization.

The development of cortical granules was followed by Anderson (2), who concluded that they arise in association with the Golgi complex. In one of the sea urchins that he described, Strongylocentrotus, the granules consisted of dense concentric lamellae, which joined an eccentrically placed dense mass. The response of cortical granules to different fixatives was studied in sea urchins by Takashima (82). He found that not only did the granules have a lamellar substructure, but in Hemicentrotus, fine particles, which were not preserved by osmium, filled the intervals between lamellae. Schuel et al. (70) have recently devised a method for separation of intact cortical granules from homogenates of sea urchin eggs by zonal centrifugation. The striking resemblance in morphology and response to fixatives of hedgehog serous granules and sea urchin cortical granules may be a reflection of basic chemical similarities in these secretory products.

In view of the relative poverty of digestive enzymes in submandibular saliva of $E$. europaeus, the question arises as to the functional significance of the highly developed secretory apparatus and complex secretory products described in this report. A clue may be furnished by the behavior of hedgehogs, as described by Burton (13). These animals often engage in a peculiar process of "self-anointing" with their saliva. After working up a salivary froth in their mouths, they liberally apply this fluid to their quills. Since these quills are their sole defense against predators, coating these structures with a toxic substance would materially enhance their effectiveness. In this connection, the reader is reminded that the only mammal with saliva definitely

FIG. 20. An acinar lumen containing partially degraded dense material from serous granules. $\times 42000$. Fig. 21. An acinar lumen with a scalloped border resulting from merocrine release of serous granules. The lumen contains the remnants of dense shells of serous granule origin. $\times 24000$. 

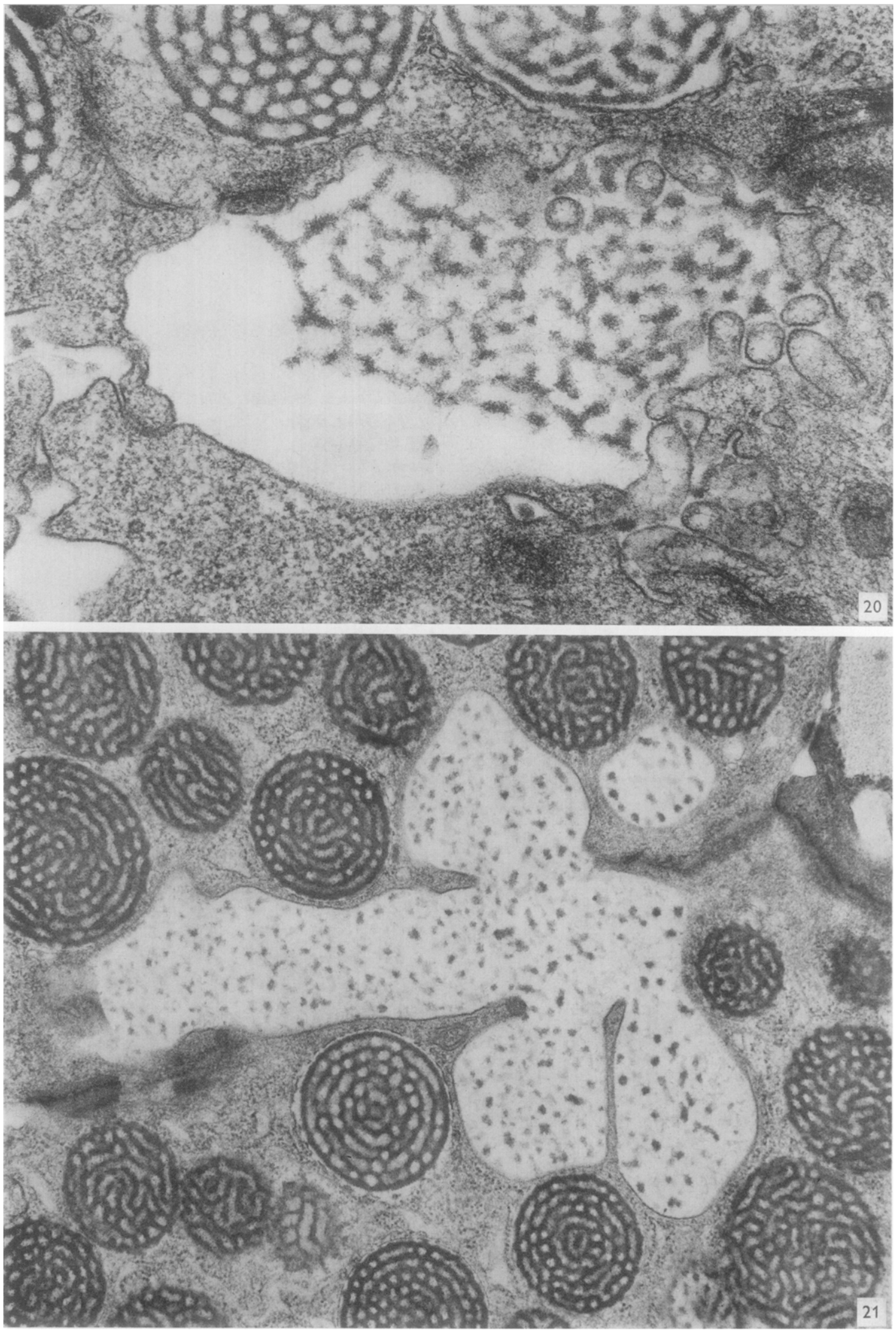
known to be toxic is the American short-tailed tree shrew, Blarina brevicauda, also an insectivore (62). Thus, it would appear that a toxicologic examination of hedgehog saliva is warranted.

This work was supported in part by National Institutes of Health Grants DE 00180 and DE 02731.

\section{REFERENCES}

1. Amsterdam, A., Ohad, I. and Schramm, M., J. Cell Biol. 41, 753 (1969).

2. Anderson, E., J. Cell Biol. 37, 514 (1968).

3. BARAJAS, L., J. Ultrastruct. Res. 15, 400 (1966).

4. Bargmann, W. and von GaudeCKer, B., Z. Zellforsch. Mikrosk. Anat. 96, 495 (1969).

5. Bassot, J.-M., Z. Zellforsch. Mikrosk. Anat. 74, 474 (1966).

6. Beams, H. W. and Kesser, R. G., J. Cell Sci. 4, 241 (1969).

7. Beams, H. W. and Seknon, S. S., Z. Zellforsch. Mikrosk. Anat. 72, 408 (1966).

8. BOER, H. H., BONGA, S. E. W. and van RoOyen, N., Z. Zellforsch. Mikrosk. Anat. 76, 228 (1967).

9. BorGir, M. B., Arch. Ital. Anat. Embriol. 68, 313 (1963).

10. Boquist, L. and Patent, G., Z. Zellforsch. Mikrosk. Anat. 115, 416 (1971).

11. Buchner, A. and Sreebny, L. M., J. Nutr. 100, 655 (1970).

12. Bulger, R. E. and Trump, B. F., Amer. J. Anat. 124, 77 (1969).

13. Burton, M., Proc. Zool. Soc. London 129, 452 (1957).

14. Combs, J. W., J. Cell Biol. 31, 563 (1966).

15. Copeland, D. E., Amer. Zool. 8, 417 (1968).

16. Cowley, L. H. and Shackleford, J. M., J. Morphol. 132, 117 (1970).

17. Dvoŕáx, M., Z. Zellforsch. Mikrosk. Anat. 99, 346 (1969).

18. Erlandson, R. A., J. Cell Biol. 22, 704 (1964).

19. Fain-Maurel, M. A., J. Microsc. (Paris) 8, 427 (1969).

20. Ferner, H. and GansLer, H., Z. Zellforsch. Mikrosk. Anat. 55, 148 (1961).

21. Fertuck, H. C. and Newstead, J. D., Z. Zellforsch. Mikrosk. Anat. 103, 447 (1970).

22. Fustia, H. and Homma, Y., Z. Zellforsch. Mikrosk. Anat. 77, 175 (1967).

23. Fusti, H. and Machino, M., Anat. Rec. 152, 81 (1965).

24. Goldfischer, S., Essner, E. and Novikofr, A. B., J. Histochem. Cytochem. 12, 72 (1964).

25. Haddad, A., Smith, M. D., Herscovics, A., Nadler, N. J. and Leblond, C. P. J. Cell Biol. 49, 856 (1971).

26. HAND, A. R., J. Cell Biol. 44, 340 (1970).

27. - Amer. J. Anat. 130, 141 (1971).

28. Hanks, C. T. and Chaudhry, A. P., Amer. J. Anat. 130, 195 (1971).

29. Harrison, G. and Philpott, D., J. Ultrastruct. Res. 16, 537 (1966).

30. Herman, L. and Sato, T., J. Microsc. (Paris) 9, 907 (1970).

31. Hirsch, G. C. and JunqueIRA, L. C. U., Naturwissenschaften 52, 195 (1965).

32. Hruban, Z., Martan, J. and Mochizuki, Y., J. Morphol. 132, 149 (1970).

33. Hruban, Z., Martan, J., Slesers, A., Steiner, D. F., Lubran, M. and Rechcigl, M., $J_{\mathrm{R} .,}$ J. Exp. Zool. 160, 81 (1965).

34. Humphreys, W. J., J. Ultrastruct. Res. 17, 314 (1967). 
35. IsHII, S., J. Ultrastruct. Res. 14, 345 (1966).

36. Jamieson, J. D. and Palade, G. E., J. Cell Biol. 34, 597 (1967).

37. Junqueira, L. C. U., in Schneyer, L. H. and Schneyer, C. A. (Eds.), Secretory Mechanisms of Salivary Glands, p. 286. Academic Press, New York, 1967.

38. Junqueira, L. C. U., Fava-De-Moraes, F. and Toledo, A. M., Arch. Oral Biol. 12, 151 (1967).

39. Kanda, T., Mayfield, E. D., Jr. and Ghidoni, J. J., Exp. Mol. Pathol. 9, 189 (1968).

40. Karnovsky, M. J., J. Cell. Biol. 27, 137 A (1965).

41. Kessel, R. G., Z. Zellforsch. Mikrosk. Anat. 76, 21 (1967).

42. Kim, S. K., Han, S. S. and Nasjleti, C. E., Anat. Rec. 168, 463 (1970).

43. Kohler, P. O., Grimley, P. M. and O’Malley, B. W., J. Cell Biol. 40, 8 (1969).

44. Krause, R., Arch. Mikrosk. Anat. 45, 93 (1895).

45. Kultschizky, N., Z. Wiss. Zool. 41, 99 (1885).

46. Kumegawa, M., Cattoni, M. and Rose, G. G., J. Cell Biol. 33, 720 (1967).

47. Lavker, R. M., J. Cell Biol. 41, 657 (1969).

48. Leppi, T. J. and Spicer, S. S. Amer. J. Anat. 118, 833 (1966).

49. - - Anat. Rec. 159, 179 (1967).

50. Lillie, R. D., Histopathologic Technique and Practical Histochemistry, p. 294. McGraw-Hill, New York, 1965.

51. LINDner, E., Z. Zellforsch. Mikrosk. Anat. 72, 212 (1966).

52. Loewenthal, N., Arch. Mikrosk. Anat. 71, 588 (1907-1908).

53. Luzzato, A. C., Procicchiani, G. and Rosati, G., J. Ultrastruct. Res. 22, 185 (1968).

54. Martan, J. and Allen, J. M., J. Exp. Zool. 159, 209 (1965).

55. MidsuKam, M., Okajimas Folia Anat. Jap. 41, 337 (1966).

56. Millonig, G., J. Appl. Phys. 32, 1637 (1961).

57. - J. Biophys. Biochem. Cytol. 11, 736 (1961).

58. Nieland, M. L. and Goudsmit, E. M., J. Ultrastruct. Res. 29, 119 (1969).

59. Nilsson, O. and Rutberg, U., Exp. Cell Res. 21, 622 (1960).

60. Ovtracht, L., J. Microsc. (Paris) 6, 773 (1967).

61. Parakkat, P. F. and Ellis, R. A., Exp. Cell Res. 32, 280 (1963).

62. Pearson, O. P., J. Mammal. 23, 159 (1942).

63. Philpott, D. E., Chate, A. B. and Burnett, A. L., J. Ultrastruct. Res. 14, 74 (1966).

64. Radley, J. M., Z. Zellforsch. Mikrosk. Anat. 97, 196 (1969).

65. Saleuddin, A. S. M., Can. J. Zool. 48, 409 (1970).

66. Sato, M., Noguchi, T., Yokoyama, M. and Yotsumoto, M., J. Electron Microsc. 15, 1 (1966).

67. Sato, T., Herman, L. and Fitzgerald, P. J., Gen. Comp. Endocrinol. 7, 132 (1966).

68. Schacter, H., Jabbal, I., Hudgin, R. L., Pinteric, L., McGuire, E. J. and Roseman, S., J. Biol. Chem. 245, 1090 (1970).

69. Schmidt, E. S. G., Z. Zellforsch. Mikrosk. Anat. 50, 143 (1959).

70. Schuel, H., Wilson, W. L., Wilson, J. R. and Schuel, R., J. Histochem. Cytochem. 17, 703 (1969).

71. Setoguti, T., J. Ultrastruct. Res. 27, 377 (1969).

72. Shackleford, J. M. and Wilborn, W. H., Amer. J. Anat. 127, 259 (1970).

73. Silveira, M., J. Microsc. (Paris) 6, 95 (1967).

74. Suöstrand, F. S., Exocrine Pancreas Ciba Found. Symp. 1961, p. 1.

75. De Souza Santos, H., J. Ultrastruct. Res. 16, 259 (1966). 
76. Spicer, S. S., Horn, R. G. and Leppi, T. J., in WAgner, B. M. and Smith, D. E. (Eds.), The Connective Tissue, p. 251. Williams \& Wilkins, Baltimore, Maryland, 1967.

77. Steinbrecht, R. A., Proc. Eur. Reg. Conf. Electron Microsc. 4th, Rome, 1968, Vol. II, p. 221.

78. Stempak, J. G. and Ward, R. T., J. Cell Biol. 22, 697 (1964).

79. Suemasa, H., Honma, Y. and Fujita, H., Arch. Histol. Jap. 29, 363 (1968).

80. Sydow, H., Z. Zellforsch. Mikrosk. Anat. 88, 387 (1968).

81. Taichman, N. S., J. Ultrastruct. Res. 32, 284 (1970).

82. Takashima, Y., Med. J. Osaka Univ. 19, 95 (1968).

83. TAMARIN, A., J. Ultrastruct. Res. 16, 320 (1966).

84. — J. Ultrastruct. Res. 34, 288 (1971).

85. Tandler, B., Anat. Rec. 160, 438 (1968).

86. Weinstock, A., Anat Rec. 162, 289 (1968).

87. Weinstock, A. and Albright, J. T., J. Ultrastruct. Res. 17, 245 (1967).

88. Yohro, T., Z. Zellforsch. Mikrosk. Anat. 110, 173 (1970). 